\title{
Assessing Pre-Service Teachers View On Improving Discipline in Colleges of Education in Ghana: A Study at Wesley College of Education
}

\author{
${ }^{1}$ Grace Aba Mensah ${ }^{*},{ }^{2}$ Lydia Boateng Berko, ${ }^{3}$ Grace Yeboah \\ ${ }^{1,2}$ Department of Education, Wesley College of Education, Kumasi \\ ${ }^{3}$ Department of Education, St Louis College of Education, Kumasi
}

\begin{abstract}
Education at every level is expected to affect behaviour of those who experience it. This makes discipline very essential component in delivery of education. The study was a case study designed to examine students' views on improving discipline in Colleges of Education. Data was collected from 244 respondents at Wesley College of Education in Ashanti Region, Ghana using a 4-point Likert and 5-point Likert scale questionnaire. The data were analysed using frequency and percentage. The study revealed that students viewed the concept of discipline as punishment which was generally perceived as severe. Punishment in the College included withdrawing students' privileges, in-school suspension and out-ofschool suspension among others. They regarded the causes of indiscipline to be the result of lack of students' participation in the decision making process of the school, unclear rules. Students' indiscipline was also attributed to bad training at home, students falling into bad company in school and lack of freedom for students. However disciplinary measures such as the use of guidance and counselling services, religious training, and parental involvement, had more positive responses. Based on the findings, some recommendations were made to improve discipline in Colleges of Education. For instance, there should be clarity of rules, this will enable students to understand the rules and abide by them. In addition, Students of colleges should be taught the value of self-discipline. These will help the student teacher to learn more appropriate ways to ensure discipline when they go out to practice.
\end{abstract}

Keywords: Discipline, indiscipline, punishment, pre-service teachers' self-discipline

\section{Introduction}

The issue of discipline in the world today has become everybody's business more especially in our educational institutions. It is a common thing to find students' always in conflicts with the school authorities because they disagree with the measures put in place by the authorities to check students' behaviour. Discipline as Adesina (1990) explained is readiness or ability to respect authority and observe conventional or established laws of the society or any other organisation. He again said is the means by which children are trained in orderliness, good conduct and the habit of getting the best of themselves. To Achebe (1984) discipline is obedience to the rules of natural justice. This means that in a society people live harmoniously with each other only when they are discipline. However, in school situation discipline is seen as training to obey school rules and regulations. Discipline to Mumthas, Munavvir, and Gafoor, (2014) means a decent and well-mannered behaviour that leads to harmony, show reverence for authority, love for orderliness, enthusiasm to perform responsibilities through consistency and competence, and high sense of responsibility that brings about sense of integrity. Understanding discipline in this way, there is no doubt that discipline is important in the school system.

Many school practices contribute to the development and prevalence of anti-social behaviour and the potential for violence. Because of the nearly exclusive emphasis on detecting individual child or youth characteristics that predict anti-social behaviour and violence, many important systemic variables are often overlooked as contributors (Colvin, Kame'enui \& Sugai, 1993). These include, among others: Failure to individualize instruction and support to adapt to individual differences (e.g. ethnic and cultural differences, 
gender, disability); Disagreement and inconsistency of implementation among staff members; Failure to reward compliance to school behaviour expectations; Lack of opportunity to learn and practice pro-social interpersonal and self-management skills; and Failure to assist students from at-risk (e.g., poverty, racial/ethnic minority members) backgrounds to bond with the schooling process.

Ineffective disciplinary practices are known to be one of the factors affecting discipline. Research investigations which have yielded information on effective disciplinary practices have also produced findings about ineffective practices. It is important for educators to be aware of the strategies research has shown to be ineffective, in part because this knowledge can assist them in planning local programs, and in part because, unfortunately, some of these practices continue to be widely used. Ineffective practices include:

- Vague or unenforceable rules. The importance of clear rules becomes obvious when observing, as researchers have, the ineffectiveness of "rules" such as, "be in the right place at the right time" (Doyle, 1989).

- Teachers ignoring misconduct. Both student behaviour and attitudes are adversely affected when teachers ignore violations of school or classroom rules (Emmer, \& Evertson, 1983). Researchers have suggested that teacher involvement in a leadership capacity had a positive effect on school improvement (Bolkman \& Goodboy, 2009; Leithwood, Pattern, \& Jantzi, 2010) therefore teachers are expected to cheek student behaviour and correct any misconduct.

- Ambiguous or inconsistent teacher responses to misbehaviour. When teachers are inconsistent in their enforcement of rules, or when they react in inappropriate ways (such as lowering students' grades in response to misbehaviour), classroom discipline is generally poor (Gottfredson, 1989).

- Punishment which is excessive or which is delivered without support or encouragement for improving behaviour. Studies have showed that teachers will experience fewer challenging behaviours when they respond to students' psychological needs positively rather than meting out punishments (Beaty- O'Ferrall, Green, \& Hanna, 2010; Gregory \& Cornell, 2009).

- Out-of-school suspension. Once again, minority students are overrepresented in out of- school suspension rates (Doyle, 1989; Denice, Gross, \& Rausch 2015). Moreover, research does not support the use of out-of-school suspension. As Slee (1986) points out, suspension doesn't help the suspended student, nor does it help the other students, because school staff simply get rid of troublesome students rather than changing the school environment in such a way as to prevent/reduce discipline problems.

Again Denice, Gross, and Rausch (2015) are of the view that first, students who are not in school are missing out on learning opportunities and secondly suspension deny students access to teaching and learning. Wayson (1986) also said, over 90 percent of suspensions occur over behaviours which are more irritating and annoying than truly serious. Wayson noted that discipline policies should be written and enforced in such a way that suspension, if it is used at all, is not used for these less-serious infractions.

Often when a student misbehaves, the first line of response involves increasing monitoring and supervision of the student, restating rules, and delivering sanctions example, referrals to the office, out of school suspension, and/or loss of privileges. The administrator may come to a point of frustration and attempt to establish a "bottom line" for disruptive students. Dupper, Theriot, and Craun (2009) supported this contention, reporting out-of-school and in-school suspensions were mostly used for infractions such as disrespect and non-cooperation. An unintended consequence of such disciplinary measures leads to more negative learning outcomes for students (Burke, Oats, Ringle, Fichtner, \& DelGaudio, 2011). The results of another research studies performed on different educational levels, revealed the fact that students perceive discipline as punishment and getting dismissed from the school as well as the school administration's absolute power (Turhan \& Yaras, 2013).

In fact, evidence suggests that schools using punishment practices alone promote more anti-social behaviour than those with a firm, but fair discipline system (Mayer, 1995; Skiba \& Peterson, 1999). Punishments generates a variety of problems and negative side effects to the child. Those who implement punishment 
rarely question the rules and their effects on overall development, self-esteem and interest in learning (Mumthas, Munavvir \& Gafoor 2014). Lewis (2001) on his part said punishment offers only short-time effects and again may also cause the repetition of misbehaviour or different behavioural problems. For students with chronic problem behaviour these negative practices are more likely to impair child-adult relationships and attachment to schooling rather than reduce the likelihood of problem behaviour.

Punishment alone, without a balance of support and efforts to restore school engagement, weakens academic outcomes and maintains the anti-social trajectory of at-risk students. Instead, the discipline process should help students accept responsibility, place high value on academic engagement and achievement, teach alternative ways to behave, and focus on restoring a positive environment and social relationships in the school. Kiprop (2012) argues, students discipline policies often keep too many students out of school and away from the classroom causing them to lose critical learning time. Research repeatedly shows that harsh disciplinary policies disproportionately affect students from poor backgrounds.

Haller (1992) on her side, faults the frequency of indiscipline in schools on large school population. It is a common thing to see many schools offering admission to more students than they can manage. She argues that it is very difficult to control a school that is overpopulated and this leads to student misbehaviour.

Yaroson, (2004) and Gyamera (2005) on their part attributed the indiscipline problem to wrong ideals learnt from peers. Most students in school are influenced by their friends to join companies that indulge in antisocial behaviour such as alcoholism, smoking which they are fuel for dangerous behaviours causing periodic upsurge of violence in the school. Salifu, and Agbenyega, (2016) also reported that student peer influence is among the causes of students misbehaviour. Ndakwa (2013) said some students are in the school to influence others to cause chaos and this happens when students meet with other students with different behaviours that negatively influence them. Gutuza, and Mapolisa, (2015) concluded from their study that indiscipline in schools was largely caused by peer group influence, bad company within and outside the school.

Inconsistent punitive classroom and behaviour management practices such as unfairness and inconsistency with rewards and punishments are also found to promote discipline problems in schools. Teachers and administrators fail in the proper management of student behaviour by applying equal sanctions to students who violate school rules (Yaroson, 2004).

Nelson (2002) suggests that much as students understand and misunderstand subject content in varying degrees, so do they understand and interpret rules differently. By this argument concluded that it is necessary to explain the significance, intent, meaning, and consequences of classroom regulations. Unclear rules and expectations regarding appropriate behaviour has the potential to promote indiscipline in school. Again unrealistic school rules from many African schools have a causative effect on the general students' behaviour. He made another point that educators fail to involve students in decision making because, they think students' involvement in rule making will lead students challenging the teacher's authority.

Mumthas, Munavvir and Gafoor (2014) reported from their study that teachers use undesirable disciplinary practices more than that of positive and constructive disciplinary practices. This revealed that teachers tend to use undesirable disciplinary practices like sending student away from the class, informing parents, fining, beating, standing upon the bench, making to approach the head teacher etc. Ukala 2018 reported that teachers are seen by students to respond to classroom misbehaviour by increasingly using forced discipline, which constrains the growth of sense of duty in students and diverts them from their schoolwork. Regrettably, teachers fail to increase their use of more productive techniques, such as discussions, rewards for good behaviour and involvement in decision-making.

In the school system, teaching goes beyond gathering students for learning. It further looks at discipline which forms an integral part of it. The school through administrators and teachers have power and authority to discipline students to ensure good behaviour. The effectiveness of the teacher's role in directing the behaviour will depend upon the latter's acceptance of his leadership role. This is where students' assessment of the teacher's personality becomes relevant. If students have a poor opinion of the ability of their teacher to persuade them to adopt desirable patterns of behaviour, it is less likely they will be co-operative. In this case, a teacher can hardly serve as role model for his or her students. This situation is most unfavourable for 
proper moral development. For if the teacher fails to inspire good behaviour in his students through persuasion and co-operative ventures, he or she may be compelled to abandon such rational methods and resort to coercion and punishment.

It clear that the teacher is charged with the responsibility of helping his students to modify or shape their behaviour to conform to accepted pattern and standard. Nevertheless, achieving discipline cannot, materialize in vacuum, it is the fruit of co-operative work, willingly undertaken and efficiently completed. It should be the goal of the school to strengthen the desire for co-operation and give students opportunities to translate it into practice. Discipline must enable the performance, freedom, choice and autonomy for both the teacher and the student. Such practices are very necessary in schools to maintain disciplinary (Mumthas, Munavvir \& Gafoor 2014).

Mostly students perceived discipline as a phenomenon guiding their behaviour, maintaining the order, and as being necessary for the social life. Learning and development, self-control, protection mechanism, planned and ordered study, as well as collaboration are further positive perceptions of discipline. However the perception of students on the other hand tend to be negative, where usually power and control is exercised by teachers. Students are of the view that punishment should not involve physical violence and that it should be reasonable. Further expectations of the students are that teachers may warn students without shouting, positive means to address individual differences, informing everybody about the rules rather than using punishment. Students' perception about discipline was usually affected by their teachers followed by their family and the school administration respectively. Discipline (mostly positive) is usually described as a phenomenon determining behaviour and organizing the social life.

Buku and Taylor (2006) said guidance services including orientation service helps student to become adjusted and established in the school environment where they are able to meet the standard of behaviour set up by the school. They said this service familiarizes the new students with information about school routine, the school traditions, rules and regulations, facilities and personnel. The service makes students realise they are required to meet the high academic demand of the school as well as moral values and ethical standards. A well organised guidance and counselling services could contribute significantly to easing the tensions brought about by indiscipline behaviour in the schools (Salifu \& Abgenyega, 2016)

It is a common belief that religion is able to manage behaviour (Hoon, 2014). Through the study of technologies deployed by the school in its inculcation of discipline and character building. The examination of the school's religious education practices provides insight into the perceptions of the school management, teachers and students with regard to various ethical, moral and religious issues (Hoon). The study revealed that Christian schools teach Christian doctrines to promote discipline in school. It was concluded that Christian Religious Education and other religious doctrines prepare learners to be morally upright (Hoon 2014). Ekpo (1996) on the other hand argued that parents should not be interested only in sending their wards to school but should also play active role in helping the school's pursuit to maintain discipline.

Another report showed that the students negative perception about discipline is derived from the methods used to deal with discipline problems. According to the views of the participants, discipline in the classroom is provided through the classroom rules and the teachers usually apply warning, shouting/scolding, and punishment (giving a minus, sending the student to the school administration, etc. (Nelson, 2002)

A current view in Ghana is that the process of socialisation should, besides the achievement of other worthwhile objectives, aim at the promotion of discipline in the society. It can be stated that the teacher's main role in this connection is that of functioning as an agent of socialisation. Stake holders of education always emphasised the importance of the role of teachers as agents for promoting understanding and tolerance among students. This role of the teacher is partly vicarious and partly autonomous; it is ambivalent in a way. The teacher's role is vicarious in the sense that he performs his functions precisely as a delegate of the state or government, church, school board and family. In other words, the teacher represents society which authorizes him to teach. For the stability and progress of society and school, it is necessary for each new generation to learn and understand the society's culture, skills and behaviour patterns.

In traditional societies where the scope of education is limited, socialisation is largely informal and has little involvement with professional teachers. Within the context of formal education, however, the teacher's role 
is greater. Whenever, he engages himself with the complex task of transmitting knowledge and skills, cultural heritage and values, the teacher acts in his own right as a professional.

Colleges of Education are educational institutions charged with the responsibility for training and preparing teachers academically and professionally for instructional work as well as non-instructional supportive functions at the pre-tertiary level where young children are trained (Colleges of Education Act, 2012). Therefore, the student teachers after training are expected to have a better perspective of discipline than the child they are going to teach.

\section{Statement of the Problem}

It is important to keep the ultimate goal in mind while working to improve school discipline. As Duke (1990) points out, the goal of good behaviour is necessary, but not sufficient to ensure academic growth. Effective school discipline strategies seek to encourage responsible behaviour and to provide all students with a satisfying school experience as well as to discourage irresponsible behaviour.

The misbehaviour of children is common in all schools although most schools manage to keep this within tolerable limits. Occasionally, however, poor disciplinary management within the school can cause a more general breakdown in order. Gutuza, and Mapolisa, (2015) concluded that indiscipline in schools was largely caused by peer group influence, bad company within and outside the school.

Ozigi (1984) stated that despite all the effort by the school authorities to maintain discipline there have been frequent complaints about the decline in the standard of discipline in many schools. He said while the general public is deeply concerned about the problem, it has not been able yet to identify the basic cause or to find a satisfactory remedy to the problem.

In Ghana, Colleges of Education Act, 2012 established colleges of education to train students to acquire the necessary professional competencies for teaching in pre-tertiary institutions. This training could not be complete if the pre-service teachers do not possess the right viewpoint about discipline. Ukala 2018 reported that teachers are seen by students to respond to classroom misbehaviour by increasingly using forced discipline, which constrains the growth of sense of duty in students and diverts them from their schoolwork. According to Farrant (1985) the teacher training colleges have the responsibility of inculcating or reenforcing discipline in colleges of education to enable pre-services teachers to do likewise later in their professional career. However, it is common to find college students in conflict with their college administrators when they make choices counter to the expectations of the institution and disciplinary measures are implemented. This conflict might be as a result of the different views pre-service teachers may have on disciplinary measures hence, this study seek to assess pre-service teachers view on disciplinary measures implemented by their college authorities. Again as far as we know most studies on discipline are carried out at the first and second cycle levels of education therefore, this study is going to fill that gap in literature.

\section{Research Objectives}

The study is focused on the following:

1. Identify the factors affecting discipline in Colleges of Education in Ghana.

2. Assessing pre-service teachers view on improving discipline in the Colleges of Education in Ghana.

\section{Research Questions}

This study was guided by the following research questions:

1. What do pre-service teachers in Colleges of Education in Ghana regard as the factors affecting discipline?

2. What views do pre-service teachers in Colleges of Education in Ghana hold about discipline in their institutions?

\section{Purpose of the Study}

The purpose of this study is to assess the pre-service teachers view on improving discipline in colleges of education in Ghana

\section{Methodology}


Case study research design was adopted for the study. A case study design is the investigations of an individual, group, institutions or other social unit. Robson (2004, p. 89) regards the design as 'development of detailed, intensive knowledge about a single 'case', or of a small number of related 'cases'. It also refers to the use of discipline approach to obtain an in-depth analysis of a person, group, and phenomenon. The design provides opportunity for in- depth study about a situation or event (Cohen, Manion, \& Morrison, 2004). It also provides a systemic way of looking at event, collecting of data, analysing information and reporting on it.

Wesley College of Education in the Ashanti Region of Ghana was considered for the study. The college was chosen because it is one of the colleges that have high student's population, and also a mixed school. Based on these reasons the college was considered appropriate for the study. The population for the study was all level 100 and 200 pre-service student teachers of Wesley College of Education numbering about 800 excluding the final year students. A sample of 250 students was selected for the study. To ensure a representative sample of the population stratified random sampling technique was used to obtain the number of respondents from the two year groups. A total sample size of 250 was determined using the mathematical formula: $\mathrm{n}=\mathrm{N} /\left[1+\mathrm{N}(\alpha)^{2}\right]$ where $\mathrm{n}=$ sample size; $\mathrm{N}=$ sampling frame; $\alpha=$ confidence level (Adei \& Kunfaa, 2007). A simple random sampling technique was used to obtain the actual respondents of each group through a computerized table of random method. The sample size obtained for the 2 year levels were: Level $100=125$ and Level $200=125$. The instrument that was used by the researchers for the study was a set of self-develop questionnaire for the students. The questionnaire was made up of mostly close-ended items. The questionnaire was made up of three main parts or sections. The first part dealt with the background or personal data of the respondents. The second part was to elicit information to measure the pre-service teachers' views on discipline. It consisted of 12 items constructed on a 4-points Likert scale with the responses: strongly agree (SA), Agree (A), Disagree (D) and Strongly Disagree (SD). The Third part was to seek information on factors that contribute to student indiscipline in the college. It consisted of 12 items constructed on a 5-points Likert scale with the responses: To a very large extent, To a large extent, To some extent, Average and to a least extent. The questionnaire was first administered in a pilot study in another college to about twenty students and the Cronbach alpha was 0.78 . The pilot study was conducted to assess the validity (internal consistency) and reliability of the questionnaire to enhance its accuracy for the data collection. The questionnaire was administered by the researchers to the participants directly. The number of questionnaires which were successfully completed and returned was 241 . This represents a return rate of $90 \%$. Administration and retrieval was on the spot this was used to improve the return rate. Meanwhile the necessary ethical procedures required were followed. Participants were made to indicate their willingness to participate in the study also anonymity and confidentiality was ensured. The researchers distributed copies of the questionnaires to the respondents. Descriptive statistics was used. The main statistical tool that was used for analysing the data on each of the research questions was percentages and frequencies. Appropriate tables were used to present the data. The frequency and percentage tables enabled the researchers to have an overall view of the findings.

\section{Results and Discussions}

\section{Introduction}

The problem addressed in this study was assessing the pre-service teachers view on improving discipline as well as identifying the factors affecting discipline in the Colleges of Education in Ghana. In this section, the data collected through questionnaire is presented and analysed. The findings are discussed and presented under the research questions 1 and 2

\section{Research Questions 1: What do pre-service teachers in Colleges of Education in Ghana Regard as the Factors Affecting Discipline?}

Pre-service teachers responded to questionnaire on what they regard as the factors affecting discipline. The responses are analysed and presented in Table 1. 
Table 1: Information on causes of indiscipline

\begin{tabular}{|c|c|c|c|c|c|c|c|c|c|c|c|c|}
\hline \multirow{2}{*}{$\begin{array}{l}\text { Cause of } \\
\text { indiscipline } \\
\begin{array}{l}\text { Bad training at } \\
\text { home }\end{array}\end{array}$} & \multicolumn{2}{|c|}{$\begin{array}{l}\text { To a very } \\
\text { large } \\
\text { extent } \\
\text { No \% }\end{array}$} & \multicolumn{2}{|c|}{$\begin{array}{l}\text { To a large } \\
\text { extent }\end{array}$} & \multicolumn{2}{|c|}{ Average } & \multicolumn{2}{|c|}{$\begin{array}{l}\text { To some } \\
\text { extent }\end{array}$} & \multicolumn{2}{|c|}{$\begin{array}{l}\text { To least } \\
\text { extent }\end{array}$} & \multicolumn{2}{|c|}{ Total } \\
\hline & 78 & 32.2 & 41 & 16.9 & 47 & 19.4 & 53 & 21.9 & 23 & 9.5 & 242 & 100 \\
\hline $\begin{array}{l}\text { Overcrowding } \\
\text { in halls }\end{array}$ & 50 & 20.7 & 49 & 20.3 & 58 & 24.1 & 39 & 16.2 & 45 & 18.7 & 241 & 100 \\
\hline $\begin{array}{l}\text { Lack of freedom } \\
\text { for students to } \\
\text { operate }\end{array}$ & 66 & 27.6 & 54 & 22.6 & 48 & 20.1 & 47 & 19.7 & 24 & 10.0 & 239 & 100 \\
\hline $\begin{array}{l}\text { Falling into bad } \\
\text { company }\end{array}$ & 102 & 42.3 & 50 & 20.7 & 39 & 16.2 & 26 & 10.8 & 24 & 10.0 & 241 & 100 \\
\hline $\begin{array}{l}\text { Unfairness and } \\
\text { hash treatment } \\
\text { of student by } \\
\text { teachers }\end{array}$ & 65 & 27.0 & 46 & 19.1 & 56 & 23.2 & 41 & 17.0 & 33 & 13.7 & 241 & 100 \\
\hline $\begin{array}{l}\text { Poor socio- } \\
\text { economic } \\
\text { background of } \\
\text { students }\end{array}$ & 51 & 21.3 & 65 & 27.2 & 57 & 23.8 & 44 & 18.4 & 22 & 9.2 & 239 & 100 \\
\hline $\begin{array}{l}\text { Unclear school } \\
\text { rules }\end{array}$ & 53 & 22.7 & 57 & 24.5 & 58 & 24.9 & 37 & 15.9 & 28 & 12.0 & 233 & 100 \\
\hline $\begin{array}{l}\text { Failure to reward } \\
\text { compliance to } \\
\text { school behaviour } \\
\text { expectations. }\end{array}$ & 47 & 19.6 & 50 & 20.8 & 67 & 27.9 & 47 & 19.6 & 29 & 12.1 & 240 & 100 \\
\hline $\begin{array}{l}\text { Excessive use of } \\
\text { punishment }\end{array}$ & 74 & 31.5 & 50 & 21.3 & 48 & 20.4 & 44 & 18.7 & 19 & 8.1 & 235 & 100 \\
\hline $\begin{array}{l}\text { Teachers } \\
\text { Ignoring student } \\
\text { Misconduct }\end{array}$ & 55 & 22.8 & 47 & 19.5 & 36 & 14.9 & 48 & 19.9 & 55 & 22.8 & 241 & 100 \\
\hline
\end{tabular}

The first research question was on factors of indiscipline in the college. In analysing this part of the questionnaire and for purposes of clarity, scores of 'to a very large extent' and 'to a large extent' were put together and regarded as 'to a large extent', while those of 'to some extent' and 'to least extent' were also put together and regarded as 'to some extent', however 'average' was made to stand on its own. The average response suggests that respondents were not certain about the item. Bad training at home was the first item and about $49 \%$ of the respondents said students' indiscipline was as a result of bad training at home. Those who did not consider bad training at home formed about $30 \%$, with the overcrowding in halls of residence 
/classrooms $41 \%$ of the students agreed that it can be cause of indiscipline as against $37 \%$ of respondents who did not support that.

It came out of the results again that those who supported lack of freedom for students to operate represent about $51 \%$ which is more than those who reported to some extent which was about $29 \%$. Regarding bad company causes indiscipline, $63 \%$ favoured the large extent where $21 \%$ indicated some extent. Students who believe to a large extent there is unfairness and harsh treatment of students by teachers were more than those who reported otherwise. The percentages were $46 \%$, and $31 \%$ respectively. Those who reported to a large extent the socio-economic background of people usually influences their behaviour was about $48 \%$, those who reported to some extent formed about $27 \%$.

With unclear school rules, $47 \%$ reported to a large extent can cause indiscipline in schools on the other hand $28 \%$ were not in favour. With the failure to reward compliance to school behaviour expectations. $41 \%$ responded that to a large extent causes indiscipline as against 32\% responded to some extent. Also 53\% said to a large extent excessive use of punishment causes indiscipline however, 26\% responded to some extent. There was no difference between responses on whether teachers ignore misconduct, both to a large extent and to some extent were $43 \%$.

\section{Research Questions 2: What Views Do Pre-service teachers in Colleges of Education in Ghana Hold about Discipline in Their Institutions?}

Pre-service teachers responded to questionnaire on what views they hold about discipline in their institutions. The responses are analysed and presented in Table 2.

\section{Table 2: Information on students' views on discipline}

\begin{tabular}{|c|c|c|c|c|c|c|c|c|c|c|}
\hline \multirow[t]{2}{*}{ Students view } & \multicolumn{2}{|c|}{$\begin{array}{l}\text { Strongly } \\
\text { Agree }\end{array}$} & \multicolumn{2}{|c|}{ Agree } & \multicolumn{2}{|c|}{ Disagree } & \multicolumn{2}{|c|}{$\begin{array}{l}\text { Strongly } \\
\text { Agree }\end{array}$} & \multicolumn{2}{|c|}{ Total } \\
\hline & No & $\%$ & No & $\%$ & No & $\%$ & No & $\%$ & No & $\%$ \\
\hline $\begin{array}{l}\text { Punishment } \\
\text { meted out in } \\
\text { the college is } \\
\text { severe }\end{array}$ & 57 & 24.1 & 90 & 38.0 & 66 & 27.8 & 24 & 10.1 & 237 & 100 \\
\hline $\begin{array}{l}\text { Application of } \\
\text { corporal } \\
\text { punishment }\end{array}$ & 27 & 11.5 & 63 & 26.8 & 80 & 34.0 & 65 & 27.6 & 235 & 100 \\
\hline $\begin{array}{l}\text { Punishment } \\
\text { includes } \\
\text { withdrawal of } \\
\text { privileges }\end{array}$ & 57 & 24.1 & 75 & 31.6 & 67 & 28.3 & 38 & 16.0 & 237 & 100 \\
\hline $\begin{array}{l}\text { Punishment } \\
\text { includes in } \\
\text { school } \\
\text { suspension }\end{array}$ & 61 & 25.4 & 121 & 50.4 & 33 & 13.8 & 25 & 10.4 & 240 & 100 \\
\hline $\begin{array}{l}\text { Punishment } \\
\text { includes out of } \\
\text { school } \\
\text { suspension }\end{array}$ & 46 & 19.3 & 88 & 37.0 & 64 & 26.9 & 40 & 16.8 & 238 & 100 \\
\hline $\begin{array}{lc}\text { Rules } & \text { for } \\
\text { ensuring } & \text { on } \\
\text { discipline } & \text { are } \\
\text { not clear } & \\
\end{array}$ & 47 & 19.7 & 97 & 40.8 & 64 & 26.9 & 30 & 12.6 & 238 & 100 \\
\hline
\end{tabular}




\begin{tabular}{|l|l|l|l|l|l|l|l|l|l|l|}
\hline $\begin{array}{l}\text { Strong } \\
\text { religious } \\
\text { training }\end{array}$ & 153 & 64.8 & 67 & 28.4 & 7 & 3.0 & 9 & 3.8 & 236 & 100 \\
\hline $\begin{array}{l}\text { Students are } \\
\text { involve in the } \\
\text { decision } \\
\text { making }\end{array}$ & 35 & 14.6 & 61 & 25.4 & 37 & 15.4 & 107 & 44.6 & 204 & 100 \\
\hline $\begin{array}{l}\text { College } \\
\text { rewards } \\
\text { students effort }\end{array}$ & 37 & 15.4 & 87 & 36.3 & 50 & 20.8 & 66 & 27.5 & 240 & 100 \\
\hline $\begin{array}{l}\text { Guidance and } \\
\text { counselling } \\
\text { services to } \\
\text { improve } \\
\text { behaviour }\end{array}$ & 60 & 25.1 & 72 & 30.1 & 51 & 21.3 & 56 & 23.4 & 239 & 100 \\
\hline $\begin{array}{l}\text { Encouragement } \\
\text { to improve } \\
\text { students } \\
\text { behaviour }\end{array}$ & 86 & 36.1 & 103 & 43.3 & 29 & 12.2 & 20 & 8.4 & 238 & 100 \\
\hline $\begin{array}{l}\text { Involvement of } \\
\text { parent to } \\
\text { improve } \\
\text { discipline }\end{array}$ & 79 & 33.2 & 91 & 38.2 & 43 & 18.1 & 25 & 10.5 & 234 & 100 \\
\hline
\end{tabular}

In analysing this part of the questionnaire and for purposes of clarity and easy comparisons, the scores of 'strongly agree' and 'agree' were put together and regarded as agree, while those of 'disagree' and 'strongly disagree' were regarded as disagree. From the table $62 \%$ of the respondents agreed that the punishments were severe as against 38\% who disagreed. Regarding the application of corporal punishment 39\% said they agreed contrary to $61 \%$ who disagreed. Also $56 \%$ agreed that students' privileges were withdrawn as a way of punishment, $44 \%$ disagreed

As high as $75 \%$ agreed that punishment given to students included in-school suspension, this $25 \%$ disagreed. Similarly, 56\% agreed that out-of-school suspension was used to punish misbehaviour $44 \%$ disagreed. the results revealed that $61 \%$ agreed school rules for ensuring discipline are not clear $39 \%$ disagreed, strong religious training had 93\% agreed with only 7\% disagreed, $40 \%$ respondents agreed that students are involve in decision making process in the school as $60 \%$ who disagreed. It came out of the results that those who reported that the college rewarded students' effort were more than those who reported otherwise. The percentage of those who agreed was about $52 \%$ agreed the college rewarded students' effort as against about 48\% who disagreed, guidance and counselling services to improve behaviour 55\% agreed as against $45 \%$ disagreed

As many as $89 \%$ said they agreed that they are encouraged by the school administration to improve behaviour as against $11 \%$ of respondents who disagreed. Many respondents said parents should be involved to improve discipline. The percentage of those who agreed was about $71 \%$ as against $29 \%$ disagreed.

\section{Discussion}

The information from the study revealed that bad training at home, overcrowding at halls of residence /classrooms, too many restrictions (lack the freedom to operate) on students, bad company are some factors of students' misbehaviour. The findings confirm many of the literature. For instance, Gyan, et al. (2015); Madziyire, (2010); Edwards, (2004); and Wright and Kate, (2003) present the argument that nowadays parents spend less time at home with their children hence, fail to give the appropriate moral training their children need. Haller (1992) on his part attributed the frequency of indiscipline in schools on large school 
population. This assertion was supported by majority of the respondents that overcrowding at halls/classrooms leads to indiscipline. Colvin, Kame'enui and Sugai, (1993) affirms that many school practices including lack of opportunity to learn, practice pro-social interpersonal and self-management skills contribute to the development and prevalence of anti-social behaviour and the potential for violence. This argument agrees with the response of students that there are too many restrictions on them which limit their interpersonal and self-management development. Students report on bad company is in agreement with Gutuza, \& Mapolisa, (2015) conclusion that indiscipline in schools is largely caused by poor group influence, bad company within and outside the school. This finding also conform with Salifu, \& Agbenyega, (2016), Yaroson, (2004) and Gyamera (2005) who attributed indiscipline in school to negative peer influence. This agrees with the saying that "bad company corrupt good character".

Students' reported other factors such as, unfairness and harsh treatment of students, unclear school rules, excessive use of punishment and poor socio economic background, failure to reward compliance to school behaviour expectations among others may lead to indiscipline. It is reported from various studies that these are some common causes of indiscipline in school. Gottfredson (1989) reported that understanding of the school rules promote good behaviour among students. Again Nelson (2002) suggested that much as students understand and misunderstand subject content in varying degrees, so in the same way they understand and interpret rules differently. By this argument concluded that it is necessary to explain the significance, intent, meaning, and consequences of classroom regulations to student.

Report on excessive use of punishment is consistent with (Mumthas, Munavvir \& Abdul 2014; Lewis 2001; Skiba \& Peterson, 1999) reports that, punishments generate a variety of problems and negative side effects which include indiscipline. They also argued that excessive punishment offers only short-time effects and again may also cause the repetition of misbehaviour or different behavioural problems. This suggests that using punishment practices alone promote more anti-social behaviour than those with proper discipline system. Again, failure on the part of teachers to assist students from poor socio economic background agrees with Colvin, et al. (1993) argument that teachers fail to assist students from at-risk (e.g., poverty, racial/ethnic minority members) backgrounds to bond with the schooling process. Interestingly, there was no difference between responses of students as to whether teachers ignore misconduct.

The information from the study also revealed that what college students view as means of ensuring discipline include severe punishments, withdrawal of students' privileges, adopt in-school suspension, outof-school suspension. These findings are consistent with Mumthas, Munavvir \& Abdul (2014) that teachers use undesirable disciplinary practices more than that of positive and constructive disciplinary practices. Practices like sending students away from the class, withdrawal of privileges, involving them in discussions and decision making have been common disciplinary measures that are usually used by many teachers and administrators. Sadik (2018) on his part argued that punishment should not involve physical violence and that it should be reasonable. Ensuring discipline in school must include informing everybody about the rules rather than using punishment that are severe on students. Turhan and Yaras, (2013), Yalcin and Erginer, (2017) mentioned in their reports from studies made at different educational levels, that students perceive discipline as punishment and getting dismissed from the school as well as the school administration's absolute power.

Other findings on student's views on measures to improve discipline which include, rewarding students' effort, the use of guidance and counselling services, religious training, parental involvement, and advice from the school administrators among others agree with Mayer, (1995); Skiba \& Peterson, (1999) argument that schools using punishment practices alone promote more anti-social behaviour than those with a firm, but fair discipline system. Students' responses suggest that the college in its quest to improve discipline also apply these positive measures. This finding is rather inconsistent with Mumthas, Munavvir \& Abdul (2014) arguments that teachers use undesirable disciplinary practices more than that of positive and constructive disciplinary practices. Though the students reported the use of negative practices they still considered others as positive. Pace and Hemmings (2007) suggestion that different approaches to student discipline are reasons for negativity in their behaviour. They said some teachers may use harsh punishments to correct student misbehaviour where other teachers may use support to win student trust to improve behaviour. Buku and Taylor (2006) said guidance services including orientation service helps student to become adjusted and 
established in the school environment where they are able to meet the standard of behaviour set up by the school. They said this service enables especially new students learn the school traditions, rules and regulations to enable them function well in school. This suggests that using counselling services can be used to improve students' behaviour. Students' view on the college using religious training to improve discipline is in agreement with Hoon (2014) findings that Christian schools teach Christian doctrines to promote discipline in school. Ekpo (1996) argued that parents should support the school to maintain discipline. This argument supports the students' views.

Majority of the students disagreed that they are involve in decision making. This view of students conforms to Ukala (2018) report that teachers in using more productive techniques, fail to involve students in decision-making. Nevertheless, regarding the application of corporal punishment students disagreed that the college used that to improve discipline. Meaning that teachers and administrators do not apply corporal punishment as disciplinary measure in the college of education. This report is inconsistent with Dupper, Theriot, and Craun (2009) and Burke, Oats, Ringle, Fichtner, and DelGaudio, (2011) who reported that some administrators use out-of-school suspension which leads to more negative learning outcomes for students.

\section{Conclusion}

From the findings it can be concluded that pre-service teachers have diverse views about measures to ensure discipline in the college. Even though it appears they have negative views giving the necessary attention to them can improve their views and discipline problems in the colleges. The major factors of indiscipline include bad training at home, overcrowding at halls of residence /classrooms, too many restrictions, bad company, unfairness and harsh treatment of students, unclear school rules and failure to reward compliance among other things.

\section{Reference}

[1.] Achebe, C. (1984). The trouble with Nigeria. Heinemann.

[2.] Adesina, S. (1990). Educational Management Enugu: Fourth Dimension Publishers.

[3.] Beaty-O'Ferrall, M. E., Green, A., \& Hanna, F. (2010). Classroom management strategies for difficult students: Promoting change through relationships. Middle School Journal, 41(4), 4-11.

[4.] Bolkan, S., \& Goodboy, A. (2009). Transformational leadership in the classroom: Fostering student learning, student participation, and teacher credibility. Journal of Instructional Psychology, 36(4), 296-306.

[5.] Buku, D. K. \& Taylor, A. I. (2006). Basics in Guidance and Counselling

( $2^{\text {nd }}$ ed.).Winneba:

University of Education.

[6.] Bull, N. (1969). Moral Education. London: Macmillan Company.

[7.] Burke, R. V., Oats, R. G., Ringle, J. L., Fichtner, L. O. N., \& DelGaudio, M. B. (2011). Implementation of a classroom management program with urban elementary schools in lowincome neighbourhoods: does program fidelity affect student behaviour and academic outcomes? Journal of Education for Students Placed at Risk (JESPAR), 16(3), 201-218.

[8.] Cohen, L., Manion, L. \& Morrison, K. (2004). Research methods in education (5 ${ }^{\text {th }}$ ed.). London: Routledge Falmer.

[9.] Colvin, G., Kame'enui, E. J., \& Sugai, G. (1993). School- wide and classroom management: Reconceptualising the integration and management of students with behaviour problems in general education. Education and Treatments of Children, 16, 361- 381.

[10.] Denice, P., Gross, B., \& Rausch, K. (2015). Understanding student discipline practices in charters schools: A research agenda. Washington, DC: Center on Reinventing Public Education.

[11.] Doyle, W. (1989), Classroom Management Techniques. In O. C. Moles (Ed.) Strategies to Reduce Students misbehaviour. Washington DC: Office of educational Research and improvement (pp. 1131)

[12.] Duke, D. L. (1990). School organization, leadership, and student behavior. Student discipline strategies: Research and practice, 19-46.

[13.] Dupper, D. R., Theriot, M. T. \& Craun, S. W. (2009). Reducing out-of-school suspensions: Practice guidelines for school social workers. Children \& Schools, 31(1), 6-14. 
[14.] Edwards, C. H. (2004). Classroom discipline and management New York: Argosy Publishing

[15.] Ekpo, S. S. (1996), Juvenile Delinquency in Nigeria Oyo Ibom State, Abanny: Education Press.

[16.] Emmer, E. T. \& Evertson, C. M. (1983) Synthesis of Research Classroom Management. Educational Leadership, 38,342-347.

[17.] Farrant, J. S. (1985). Principles and Practice of education, England: Longman group Ltd.

[18.] Gottfreson, D.C. (1989). Developing Effective Organisations to Reduce School Disorder. In O.C. Moles (Ed) Strategies to Reduce Students misbehaviour. Washington DC: Office of educational Research and improvement (pp. 87-104.)

[19.] Gregory, A., \& Cornell, D. (2009). "Tolerating" adolescent needs: Moving beyond zero tolerance policies in high school. Theory into Practice, 48(2), 106-113.

[20.] Gutuza, R. F., \& Mapolisa, T. (2015). An analysis of the causes of indiscipline amongst secondary school pupils in Nyanga District. Global Journal of Advanced Research, 2(7), 1164-1171.

[21.] Gyamera, G. O. (2005). Perceptions of students and teachers about discipline: A case study of Adisadel College, Cape Coast. Master of Philosophy unpublished, University of Cape Coast, Ghana, Cape Coast.

[22.] Gyan, E., Baah-Korang, K., McCarthy, P., \& McCarthy, P. (2015). Causes of Indiscipline and Measures of Improving Discipline in Senior Secondary Schools in Ghana: Case Study of a Senior Secondary School in Sunyani. Journal of Education and Practice, 6(11), 19-25.

[23.] Haller, E. (1992). High school size and student indiscipline: Another asepect of the school consolidation issues. Educational Evaluation and Policy Analysis, 14 (1), 145-156

[24.] Hoon, C. Y. (2014). God and discipline: Religious education and character building in a Christian school in Jakarta. South East Asia Research, 22(4), 505-524.

[25.] Leithwood, K., Patten, S., \& Jantzi, D. (2010). Testing a conception of how school leadership influences student learning. Educational administration quarterly, 46(5), 671-706.

[26.] Lewis, R. (2001). Classroom discipline and student responsibility: The students' view. Teaching and teacher education, 17(3), 307-319.

[27.] Madziyire, N. C. (2010). Leadership and supervision. Harare, Zimbabwe Open University

[28.] Mayer, G. R. (1995). Preventing antisocial behaviour in the schools. Journal of Applied Behaviour Analysis, 28(4), 467-478.

[29.] Mumthas, N. S., Munavvir, J., \& Abdul Gafoor, K. (2014). Student and Teacher Perception of Disciplinary Practices: Types, Reasons, Consequences and Alternatives. Online Submission, 2(4), 301-308.

[30.] Ndakwa, D. (2013). A simplified guide: The making of a new student. Nairobi: Pavement Publishers.

[31.] Nelson, F. (2002). A Qualitative Study of Effective School Discipline Practices: Perceptions of Administrators, Tenured Teachers, and Parents in Twenty Schools.

[32.] Kiprop, C. J. (2012). Approaches to management of discipline in secondary schools in Kenya. International Journal of Research in Management, 2(3): 120-138.

[33.] Ozigi, A. (1984). An introduction to the foundations of education, New York: Mcmillan Publishing Co.

[34.] Pace, J. L. \& Hemmings, A. (2007). Understanding authority in classrooms: A review of theory, ideology, and research. Review of Educational Research, 77(14), 4-27.

[35.] Robson, C. (2004). Real world research ( $2^{\text {nd }}$ ed.). Padstow: Blackwell Publishing.

[36.] Sadik, F. (2018). Children and discipline: Investigating secondary school students' perception of discipline through metaphors. European Journal of Educational Research, 7(1), 31-44.

[37.] Salifu, I., \& Agbenyega, J. S. (2016). Impact of discipline issues on school effectiveness: The views of some Ghanaian principals. MIER Journal of educational studies, trends and practices, 2(1).

[38.] Slee, R. (1986). Integration: The Disruptive Student and Suspension. The Urban Review 18 (2), 87103.

[39.] Skiba, R. \& Peterson, R. (1999). School discipline at a crossroads, from zero tolerance to early response, Exceptional children 66 (3), 335-346. 
[40.] Turhan, M., \& Yaras, Z. (2013). Ogretmen ve ogrencilerin ogretmen, disiplin, mudur, sinif kurallari, odul ve ceza kavramlarina iliskin metafor algilari [Teachers' and students' metaphorical perceptions related to teacher, discipline, principal, classroom rules, reward and punishment]. Firat Universitesi Sosyal Bilimler Dergisi, 23(1), 129-145.

[41.] Ukala, C. C. (2018). Students' perception of Discipline in Public Secondary Schools in Rivers State, Nigeria. European Journal of Research in Social Sciences Vol, 6(3).

[42.] Wayson, W. W. (1986). Developing Schools with Good Discipline, Bloomington: Phi Delta Kappan.

[43.] Wright, A., \& Keetley, K. (2003). Violence and Indiscipline in Schools: Research Study Commissioned by NASUWT; Final Report. PRCI.

[44.] Yaroson, M. C. (2004). Strategies for curbing indiscipline in Nigerian schools. In Proceedings at the National Workshop on developing education: Issues of standard and sustainability in secondary schools in Nigeria. United Kingdom: ACCS. 